\title{
Zobellella denitrificans gen. nov., sp. nov. and Zobellella taiwanensis sp. nov., denitrifying bacteria capable of fermentative metabolism
}

\author{
Yu-Te Lin and Wung Yang Shieh \\ Institute of Oceanography, National Taiwan University, PO Box 23-13, Taipei, Taiwan
}

Correspondence

Wung Yang Shieh

winyang@ntu.edu.tw

Two denitrifying strains of heterotrophic, facultatively anaerobic bacteria, designated $Z \mathrm{D} 1^{\top}$ and $\mathrm{ZT}^{\top}{ }^{\top}$, were isolated from sediment samples collected from mangrove ecosystems in Taiwan. The isolates were Gram-negative. Cells grown in broth cultures were straight rods that were motile by means of a single polar flagellum. The isolates grew optimally in 1-3\% $\mathrm{NaCl}$, but $\mathrm{NaCl}$ was not an absolute requirement for growth; only strain $\mathrm{ZT}^{\top}{ }^{\top}$ grew in $13-14 \% \mathrm{NaCl}$. Both isolates grew between 10 and $45^{\circ} \mathrm{C}$, with optimum growth at $30-35^{\circ} \mathrm{C}$. They were capable of anaerobic growth by denitrifying metabolism using nitrate or nitrous oxide as terminal electron acceptors or, alternatively, by fermenting glucose, sucrose or mannitol as substrates. $\mathrm{C}_{18: 1} \omega 7 c$ was the most abundant fatty acid (32.6-35.7\%). The other major fatty acids included $\mathrm{C}_{16: 1} \omega 7 c(27 \cdot 5-29 \cdot 4 \%)$ and $\mathrm{C}_{16: 0}(20 \cdot 1-22 \cdot 0 \%)$. The two isolates had $16 \mathrm{~S}$ rRNA gene sequence similarity of $96 \cdot 8 \%$ and shared $94 \cdot 1-96 \cdot 8 \%$ sequence similarity with the most closely related species, Oceanimonas doudoroffii, Oceanimonas baumannii, Oceanimonas smirnovii and Oceanisphaera litoralis.

They could be distinguished from these species in that they were capable of fermentative metabolism, had relatively high DNA G $+\mathrm{C}$ contents $(62 \cdot 0-64 \cdot 0 \mathrm{~mol} \%)$ and contained $\mathrm{C}_{18: 1} \omega 7 \mathrm{c}$ instead of $\mathrm{C}_{16: 1} \omega 7 c$ as the most abundant fatty acid. Characterization data accumulated in this study revealed that the two denitrifying isolates could be classified as representatives of two novel species in a new genus, Zobellella gen. nov., with Zobellella denitrificans sp. nov. (type strain $\mathrm{ZD} 1^{\top}=\mathrm{BCRC} 17493^{\top}=\mathrm{JCM} 13380^{\top}$ ) as the type species and Zobellella taiwanensis sp. nov. (type strain $Z T 1^{\top}=B C R C 17494^{\top}=J C M 13381^{\top}$ ) as a second species.

Alteromonas-like bacteria belonging to the Gammaproteobacteria comprise a large group of marine, heterotrophic, polar-flagellated, Gram-negative rods that are mainly nonfermentative aerobes. Differentiation of these bacteria is impeded at the species level and even at the genus level by their similar phenotypic characteristics. Phylogeny based on $16 \mathrm{~S}$ rRNA gene sequences, however, has been utilized to classify these bacteria into a variety of families and genera, including Alteromonadaceae (Alteromonas and Glaciecola), Pseudoalteromonadaceae (Pseudoalteromonas and Algicola), Colwelliaceae (Colwellia and Thalassomonas), Ferrimonadaceae (Ferrimonas), Idiomarinaceae (Idiomarina), Moritellaceae (Moritella), Shewanellaceae (Shewanella), Psychromonadaceae (Psychromonas) and Oceanimonas and Oceanisphaera [taxonomic affiliation of Oceanimonas and Oceanisphaera at the family level remains undetermined (Ivanova et al., 2004)].

The GenBank/EMBL/DDBJ accession numbers for the 16S rRNA gene sequences of strains $\mathrm{ZD} 1^{\top}$ and $\mathrm{ZT} 1^{\top}$ are $\mathrm{DQ} 195675$ and DQ195676, respectively.

Electron micrographs of cells of strains $\mathrm{ZD} 1^{\top}$ and $\mathrm{ZT} 1^{\top}$ are available as supplementary material in IJSEM Online.
Among these genera, only Ferrimonas, Colwellia, Moritella and Shewanella are known to include fermentative facultative anaerobes (Ivanova et al., 2004).

Denitrification is the dissimilatory reduction of nitrate or nitrite to the gaseous end product $(\mathrm{s})$ nitrous oxide $\left(\mathrm{N}_{2} \mathrm{O}\right)$ or dinitrogen gas. Many Alteromonas-like species classified as Shewanella, Pseudoalteromonas and Ferrimonas have the ability to reduce nitrate to nitrite. However, only some of them, such as Shewanella denitrificans (Brettar et al., 2002), Shewanella sediminis (Zhao et al., 2005) and Shewanella decolorationis (Xu et al., 2005), are capable of denitrification. These bacteria can achieve anaerobic growth using not only nitrate, but also nitrite or nitrous oxide as the electron acceptor.

Two denitrifying bacterial strains were isolated from sediment samples collected from various estuarine mangrove ecosystems during a survey of diversity of denitrifying bacteria in estuarine and coastal environments in Taiwan. Data from this study indicated that the two isolates could achieve anaerobic growth by undertaking either denitrification or fermentation. Evidence presented in this study also 
showed that the two isolates could be classified as the type strains of two species in a new genus belonging to the Alteromonas-like Gammaproteobacteria.

Polypeptone-yeast extract (PY) broth contained the following constituents ( $\mathrm{g}$ per 1 deionized water): polypeptone (Nihon Seiyaku), 3; Bacto yeast extract (Difco), 1; NaCl, 20; $\mathrm{MgCl}_{2} .6 \mathrm{H}_{2} \mathrm{O}, 2 ; \mathrm{CaCl}_{2}, 0.005 ; \mathrm{Na}_{2} \mathrm{MoO}_{4} .7 \mathrm{H}_{2} \mathrm{O}, 0.005$; $\mathrm{CuCl}_{2} \cdot 2 \mathrm{H}_{2} \mathrm{O}, 0 \cdot 005 ; \mathrm{g} \mathrm{FeCl}_{3} \cdot 6 \mathrm{H}_{2} \mathrm{O}, 0 \cdot 005$; and $3-(\mathrm{N}-$ morpholino)-2-hydroxypropanesulfonic acid (MOPSO; Sigma-Aldrich), $4 \cdot 5$. The medium was adjusted to $\mathrm{pH} 7 \cdot 0$. Bacto agar (Difco) was added to this medium at 3 and $15 \mathrm{~g} \mathrm{l}^{-1}$ for the preparation of stab and plate media, respectively. Polypeptone-yeast extract-nitrate (PYN) broth was prepared by adding $\mathrm{KNO}_{3}$ at $2 \mathrm{~g} \mathrm{l}^{-1}$ to PY broth. Polypeptone-yeast extract-glucose (PYG) broth was prepared in two parts. The first part contained 3 g polypeptone, $1 \mathrm{~g}$ Bacto yeast extract, $20 \mathrm{~g} \mathrm{NaCl}, 2 \mathrm{~g} \mathrm{MgCl}_{2} \cdot 6 \mathrm{H}_{2} \mathrm{O}, 0 \cdot 005 \mathrm{~g}$ $\mathrm{CaCl}_{2}, 0.005 \mathrm{~g} \mathrm{Na}_{2} \mathrm{MoO}_{4} .7 \mathrm{H}_{2} \mathrm{O}, 0.005 \mathrm{~g} \mathrm{CuCl}_{2} .2 \mathrm{H}_{2} \mathrm{O}$, $0.005 \mathrm{~g} \mathrm{FeCl}_{3} \cdot 6 \mathrm{H}_{2} \mathrm{O}$ and $4.5 \mathrm{~g}$ MOPSO dissolved in $900 \mathrm{ml}$ deionized water and adjusted to $\mathrm{pH} 7 \cdot 0$. The second part contained $5 \mathrm{~g}$ glucose dissolved in $100 \mathrm{ml}$ deionized water. The two parts were autoclaved separately and mixed at room temperature. Carbohydrate-mineral (CM) liquid media were made up of two parts. Part I contained $0.54 \mathrm{~g} \mathrm{NH}_{4} \mathrm{Cl}, 20 \mathrm{~g} \mathrm{NaCl}, 2 \mathrm{~g} \mathrm{MgCl}_{2} \cdot 6 \mathrm{H}_{2} \mathrm{O}, 3 \mathrm{~g}$ $\mathrm{K}_{2} \mathrm{SO}_{4}, 0.2 \mathrm{~g} \mathrm{~K}_{2} \mathrm{HPO}_{4}, 0.01 \mathrm{~g} \mathrm{CaCl}_{2}, 0.005 \mathrm{~g} \mathrm{FeCl}_{3} \cdot 6 \mathrm{H}_{2} \mathrm{O}$, $0.005 \mathrm{~g} \mathrm{Na}_{2} \mathrm{MoO}_{4} .7 \mathrm{H}_{2} \mathrm{O}, 0.005 \mathrm{CuCl}_{2} .2 \mathrm{H}_{2} \mathrm{O}$ and $4.5 \mathrm{~g}$ MOPSO dissolved in $900 \mathrm{ml}$ deionized water and adjusted to $\mathrm{pH} 7 \cdot 0$, and part II contained $5 \mathrm{~g}$ glucose or other test carbohydrate (D-arabinose, L-arabinose, cellobiose, galactose, lactose, maltose, mannose, melezitose, melibiose, ribose, starch, sucrose, trehalose, xylose, adonitol, dulcitol, mannitol, myo-inositol, sorbitol) dissolved in $100 \mathrm{ml}$ deionized water. The two parts were autoclaved separately and mixed at room temperature.

Sediment samples collected from various estuarine mangrove ecosystems were processed within a few hours. Some wet mass (approx. $5 \mathrm{~g}$ ) of each sample was vigorously shaken in $95 \mathrm{ml}$ sterile $\mathrm{NaCl}-\mathrm{MOPSO}$ buffer $(20 \mathrm{~g} \mathrm{NaCl}$ and $0 \cdot 45 \mathrm{~g}$ MOPSO in 11 deionized water, $\mathrm{pH} 7 \cdot 0$ ). The shaken solutions were decimally diluted with the same buffer and a volume $(1 \mathrm{ml})$ of each dilution $\left(10^{3}-10^{5}\right.$ times $)$ was transferred to a rimless tube $(16 \mathrm{~mm} \times 10 \mathrm{~cm})$ containing PYN broth medium $(5 \mathrm{ml})$ in which an inverted Durham insert had been placed. All culture tubes were incubated aerobically at $25^{\circ} \mathrm{C}$ in the dark for $3-7$ days. Cultures that developed visible turbidity and produced gas (accumulated in Durham inserts) were streaked (one loopful) on PY plate medium. Individual colonies appearing on each plate were picked and purified by successive streaking on PY plates. More than 100 strains that exhibited growth and produced gas in PYN broth were isolated using this enrichment cultivation method. These isolates were maintained in PY stab medium and stored at $25^{\circ} \mathrm{C}$. Two of these isolates, strains $\mathrm{ZD}^{\mathrm{T}}$ and $\mathrm{ZT} 1^{\mathrm{T}}$, collected from the estuarine mangrove ecosystems of Chungkang, Miaoli County, and
Kuantu, Taipei, respectively, were used for the present study.

Strains $\mathrm{ZD} 1^{\mathrm{T}}$ and $\mathrm{ZT} 1^{\mathrm{T}}$ were cultivated aerobically in PY broth at $30^{\circ} \mathrm{C}$ in the dark for 2 days. The cultures were centrifuged to harvest the cells. Total genomic DNA was extracted and purified from cells using a Puregene DNA isolation kit (Gentra Systems) in accordance with the manufacturer's instructions. DNA hydration solutions of about $500 \mu \mathrm{g} \mathrm{ml}^{-1}$ were used for PCR amplification. PCR amplification of the bacterial 16S rRNA gene was conducted using a universal primer pair at positions 8-27 and 1488-1510 [Escherichia coli numbering system (Shieh et al., 2003a)]. Accessory PCR amplification was performed using either of the primer pairs at positions 8-27 and 685-704 (Lane, 1991) or positions 907-926 and 1488-1511 (Lane, 1991). The PCR mixture contained $2 \cdot 5 \mu \mathrm{l}$ DNA hydration solution, $2 \mu \mathrm{l}$ mixture of one of the primer pairs ( $5 \mu \mathrm{M}$ of each primer), $1 \mu \mathrm{l}$ mixture of the four dNTPs (Gene Teks Bioscience) (2.5 mM each), $5 \mu \mathrm{l} 10 \times$ Taq buffer (Gene Teks Bioscience), $5 \mu \mathrm{l} 10 \times \mathrm{BSA}$ (Promega) and $0.5 \mu \mathrm{l}(2 \mathrm{U}) \mathrm{Taq}$ DNA polymerase (Gene Teks Bioscience). Each sample was made up to $50 \mu \mathrm{l}$ with sterile distilled water. PCR amplification was performed in a GeneAmp PCR System 2700 (Applied Biosystems) with the following temperature profile: initial denaturation at $94{ }^{\circ} \mathrm{C}$ for $10 \mathrm{~min}, 35$ cycles of denaturation $\left(1 \mathrm{~min}\right.$ at $\left.92^{\circ} \mathrm{C}\right)$, annealing $\left(1.5 \mathrm{~min}\right.$ at $\left.52^{\circ} \mathrm{C}\right)$ and extension $\left(1.5 \mathrm{~min}\right.$ at $\left.72^{\circ} \mathrm{C}\right)$ and a final extension at $72^{\circ} \mathrm{C}$ for $4 \mathrm{~min}$. Aliquots $(2 \mu \mathrm{l})$ of the PCR products were checked for size and purity by electrophoresis at $100 \mathrm{~V}$ for 30 min on $1 \%$ agarose gels in TAE buffer (MDBio). Gels were stained with ethidium bromide $\left(1 \mu \mathrm{g} \mathrm{ml}^{-1}\right)$ for $5 \mathrm{~min}$ in TAE buffer and DNA bands appearing on the gels were examined under an image analysing system consisting of a UV transilluminator (Spectroline), a dark box (Kodak EDAS 290) and a zoom digital camera (Kodak DC290).

Sequencing of the 16S rRNA genes, alignment and comparison of the resulting sequences and reference sequences available in the GenBank database, calculation of distance matrices for the aligned sequences and reconstruction of a phylogenetic tree by the neighbour-joining method were carried out as described by Shieh et al. (2004). Bootstrap confidence values (Felsenstein, 1985) were obtained with 100 resamplings with an option of stepwise addition. Phylogenetic trees were also reconstructed using maximumparsimony (Fitch, 1971) and maximum-likelihood (Felsenstein, 1981) methods.

Cells grown in PY broth at $30^{\circ} \mathrm{C}$ for 2 days were harvested by centrifugation. Total lipids in the cells were extracted by the method of Bligh \& Dyer (1959). Individual lipids were separated by two-dimensional TLC in solvent systems described by Vaskovsky \& Terekhova (1979). They were detected on the TLC using $10 \% \mathrm{H}_{2} \mathrm{SO}_{4}$ in methanol with subsequent heating to $180{ }^{\circ} \mathrm{C}$ and using $1.3 \%$ molybdenum blue spray reagent (Sigma) for phospholipids, $2 \%$ ninhydrin (Fluka) in acetone for amino-containing lipids and Dragendorf's reagent (Fluka) for choline lipids. 
Phospholipids were quantified by the method of Vaskovsky et al. (1975). Fatty acids in whole cells grown on PY plate medium at $30^{\circ} \mathrm{C}$ for 2 days were extracted, saponified and esterified, followed by GC analysis of the fatty acid methyl esters according to the instructions of the MIDI system (Sasser, 1997). This work was performed at the Bioresources Center for Research and Collection (BCRC), Food Industry Research and Development Institute, Taiwan. The DNA $\mathrm{G}+\mathrm{C}$ content was determined by HPLC analysis (Shieh \& Liu, 1996), which was also performed at the BCRC. DNADNA relatedness between strains $\mathrm{ZD1}^{\mathrm{T}}$ and $\mathrm{ZT}^{\mathrm{T}}$ was determined as described by Shieh et al. (2003a).

Growth and other phenotypic characteristics of strains $\mathrm{ZD1}^{\mathrm{T}}$ and $\mathrm{ZT} 1^{\mathrm{T}}$ were examined by the methods of Shieh et al. (2000) with modifications and additional tests as described below. The ability to grow at different temperatures was determined in PY broth and recorded daily for up to 7 days at $15,20,25,30,35,40,45$ and $50^{\circ} \mathrm{C}$ and for 20 days at 4 and $10^{\circ} \mathrm{C}$, unless significant growth had been observed. Growth in different $\mathrm{NaCl}$ concentrations was determined in PY broth containing $0-15 \%(\mathrm{w} / \mathrm{v}) \mathrm{NaCl}$. Anaerobic growth in PY, PYN and PYG broth media in the presence or absence of $\mathrm{N}_{2} \mathrm{O}$ was examined as described by Shieh et al. (2004). Growth on various carbohydrates as sole carbon and energy sources was determined in CM media. Denitrifying activity was determined by $\mathrm{C}_{2} \mathrm{H}_{2}$ blockage and $\mathrm{N}_{2} \mathrm{O}$ reduction procedures (Shieh \& Liu, 1996). $\mathrm{H}_{2} \mathrm{~S}$ production from thiosulfate was tested as described by Shieh et al. (2004). Urease was determined with modified Christensen urea agar (Smibert \& Krieg, 1994) containing $25 \mathrm{~g} \mathrm{NaCl}^{-1}$. Tests for arginine dihydrolase, lysine decarboxylase and ornithine decarboxylase were performed in broth media containing Bacto decarboxylase base Moeller (10.5 $\mathrm{g} \mathrm{l}^{-1}$; Difco), $\mathrm{NaCl}$ $\left(20 \mathrm{~g} \mathrm{l}^{-1}\right), \mathrm{MgCl}_{2} \cdot 6 \mathrm{H}_{2} \mathrm{O}\left(2 \mathrm{~g} \mathrm{l}^{-1}\right)$ and the appropriate L-amino acid $\left(10 \mathrm{~g} \mathrm{l}^{-1}\right)$. Other constitutive enzyme activities were detected using the API ZYM system (bioMérieux Vitek). Cell suspensions used for these tests were prepared in a mineral medium $\left(0.54 \mathrm{~g} \mathrm{NH}_{4} \mathrm{Cl}, 20 \mathrm{~g} \mathrm{NaCl}, 2 \mathrm{~g}\right.$ $\mathrm{MgCl}_{2} \cdot 6 \mathrm{H}_{2} \mathrm{O}, 3 \mathrm{~g} \mathrm{~K}_{2} \mathrm{SO}_{4}, 0.2 \mathrm{~g} \mathrm{~K}_{2} \mathrm{HPO}_{4}, 0.01 \mathrm{~g} \mathrm{CaCl}_{2}$, $0.005 \mathrm{~g} \mathrm{FeCl} 3.6 \mathrm{H}_{2} \mathrm{O}, 0.005 \mathrm{~g} \mathrm{Na}_{2} \mathrm{MoO}_{4} .7 \mathrm{H}_{2} \mathrm{O}, 0.005 \mathrm{~g}$ $\mathrm{CuCl}_{2} .2 \mathrm{H}_{2} \mathrm{O}$ and $4.5 \mathrm{~g} \mathrm{MOPSO}$, dissolved in $1000 \mathrm{ml}$ deionized water and adjusted to $\mathrm{pH} 7 \cdot 0$ ). Antibiotic susceptibility tests were performed by disc diffusion methods as described previously (Shieh et al., 2003a, b). All test cultures were incubated aerobically at $30^{\circ} \mathrm{C}$ in the dark for 7 days, unless stated otherwise.

Effects of $\mathrm{pH}$, temperature and $\mathrm{NaCl}$ on growth were determined in PY broth under aerobic conditions. Strains $\mathrm{ZD1}^{\mathrm{T}}$ and $\mathrm{ZT} 1^{\mathrm{T}}$ grew at $\mathrm{pH} 6-10$, with optimum growth at $\mathrm{pH} 7-8$. No growth was observed at $\mathrm{pH} 5 \cdot 0$. Growth was observed at $10-45^{\circ} \mathrm{C}$, with optimum growth at $30-35^{\circ} \mathrm{C}$. Both strains grew in $0-12 \% \mathrm{NaCl}$, but only strain $\mathrm{ZT}^{\mathrm{T}}$ grew in $13-14 \% \mathrm{NaCl}$. Although $\mathrm{NaCl}$ was not indispensable for growth, optimal growth was observed at $1-3 \% \mathrm{NaCl}$.

Strains $\mathrm{ZD1}^{\mathrm{T}}$ and $\mathrm{ZT1}^{\mathrm{T}}$ exhibited good growth in PYN (maximum $\mathrm{OD}_{600} 1 \cdot 02-1 \cdot 05$ ) and PYG (maximal $\mathrm{OD}_{600}$
$0 \cdot 40-0 \cdot 44)$ broth media under anaerobic conditions, whereas anaerobic growth in PY broth was relatively weak (maximal $\mathrm{OD}_{600} 0 \cdot 14-0 \cdot 17$ ) unless $\mathrm{N}_{2} \mathrm{O}$ was present in the culture systems (maximum $\mathrm{OD}_{600} 0 \cdot 34-0 \cdot 73$ ) (Fig. 1). This indicated a lack of sufficient $\mathrm{NO}_{3}^{-}$and fermentable substrates for the strains in PY broth cultures. The results also suggested that the strains were capable of anaerobic growth by carrying out denitrifying metabolism with $\mathrm{NO}_{3}^{-}$or $\mathrm{N}_{2} \mathrm{O}$ as the terminal electron acceptor. Anaerobic growth in PYG broth was accompanied by a remarkable decrease in the $\mathrm{pH}$ of the medium, from $\mathrm{pH} 7 \cdot 0$ to $5 \cdot 4$ within $72 \mathrm{~h}$ (data not shown), regardless of the large buffer content (approx. $20 \mathrm{mM}$ MOPSO) in the medium. The strains could have achieved anaerobic growth in PYG by fermenting glucose, with considerable production of organic acids. In addition to glucose, both strains also showed anaerobic growth by fermenting sucrose or mannitol as substrates (data not shown).

Almost complete $16 \mathrm{~S}$ rRNA gene sequences of strains $\mathrm{ZD1}^{\mathrm{T}}$ and $\mathrm{ZT}^{\mathrm{T}}$ were determined. They were aligned and compared with all bacterial sequences available in the GenBank database. The two sequences shared $96 \cdot 8 \%$ similarity ( 48 differences out of $1478 \mathrm{nt}$ positions). The closest relatives of strains $\mathrm{ZD1} 1^{\mathrm{T}}$ and $\mathrm{ZT1}^{\mathrm{T}}$ were species of Oceanimonas and Oceanisphaera, including Oceanimonas doudoroffi,
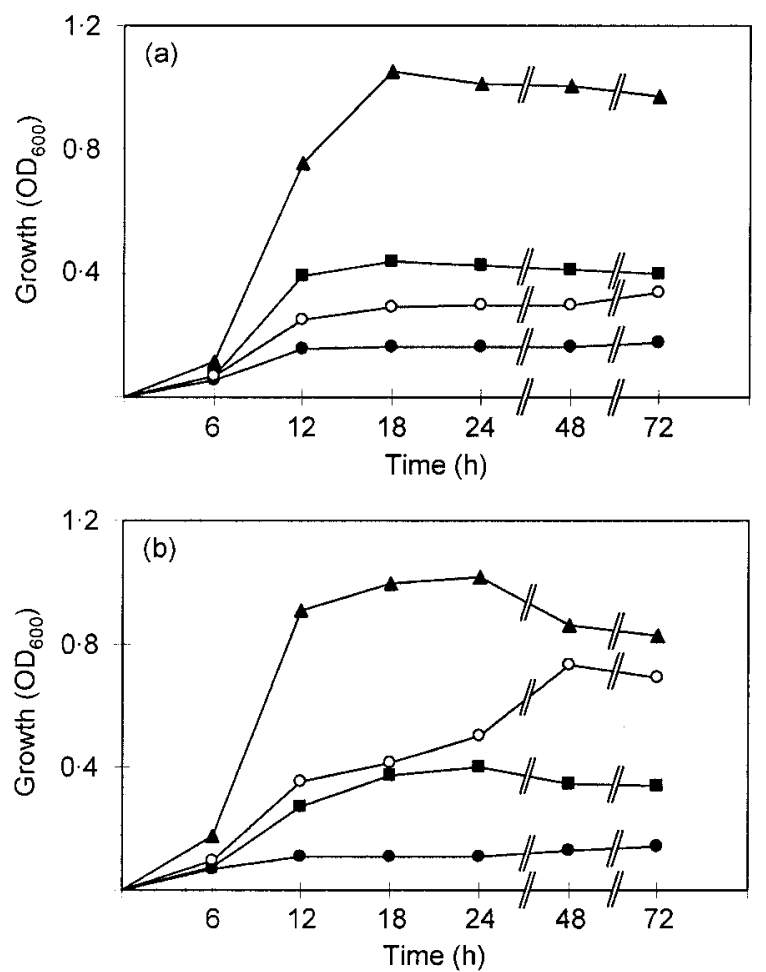

Fig. 1. Changes in $O D_{600}$ during anaerobic growth of strains $Z D 1^{\top}$ (a) and $Z 1^{\top}{ }^{\top}$ (b) in PY $(\boldsymbol{\bullet}, \bigcirc), \operatorname{PYN}(\boldsymbol{\Delta})$ and PYG (ם) broth media under argon in the presence $(\bigcirc)$ or absence $(\boldsymbol{Q}$, $\boldsymbol{\Delta}, \boldsymbol{\square})$ of $\mathrm{N}_{2} \mathrm{O}(102 \cdot 4 \mu \mathrm{mol}$ per tube). 
Oceanimonas baumannii, Oceanimonas smirnovii and Oceanisphaera litoralis. The corresponding overall $16 \mathrm{~S}$ rRNA gene sequence similarities between the strains and these species were $94 \cdot 1-96 \cdot 8 \%$. No other known bacteria shared more than $93 \%$ sequence similarity with the two isolates. A neighbour-joining tree (Fig. 2) shows the phylogenetic positions between strains $\mathrm{ZD1} 1^{\mathrm{T}}$ and $\mathrm{ZT} 1^{\mathrm{T}}$ and species of Oceanimonas and Oceanisphaera and other related taxa belonging to the Alteromonas-like Gammaproteobacteria. Similar results were obtained from maximum-likelihood and maximum-parsimony algorithms (not shown). The $16 \mathrm{~S}$ rRNA gene-based phylogeny revealed that the two isolates could be classified either as different species in a novel genus or as novel species of Oceanimonas (Fig. 2).

Strains $\mathrm{ZD1}^{\mathrm{T}}$ and $\mathrm{ZT1}^{\mathrm{T}}$ had DNA G $+\mathrm{C}$ contents of $64 \cdot 0$ and $62.0 \mathrm{~mol} \%$, respectively, which are greater than those of species of Oceanimonas $(55 \cdot 6-59 \cdot 0 \mathrm{~mol} \%$; Ivanova et al., 2005) and Oceanisphaera (56.4 mol\%; Romanenko et al., 2003). Both Oceanimonas doudoroffii and Oceanimonas baumannii had a G $+\mathrm{C}$ content of $54 \cdot 0 \mathrm{~mol} \%$ according to Brown et al. (2001), whereas the $\mathrm{G}+\mathrm{C}$ contents of the two determined by Ivanova et al. (2005) were $59 \cdot 0$ and $57 \cdot 0 \mathrm{~mol} \%$, respectively; this discrepancy between the $\mathrm{G}+\mathrm{C}$ contents remains to be clarified. Strains $\mathrm{ZD1}{ }^{\mathrm{T}}$ and $\mathrm{ZT}^{\mathrm{T}}$, like species of Oceanimonas and Oceanisphaera, contained $\mathrm{C}_{16: 0}, \mathrm{C}_{16: 1} \omega 7 c$ and $\mathrm{C}_{18: 1} \omega 7 c$ as the major cellular fatty acids (Table 1). However, the most abundant fatty acid of the isolates was $\mathrm{C}_{18: 1} \omega 7 c(32 \cdot 6-35 \cdot 7 \%)$, whereas it was $\mathrm{C}_{16: 1} \omega 7 c(40 \cdot 1-45 \%)$ in species of Oceanimonas and

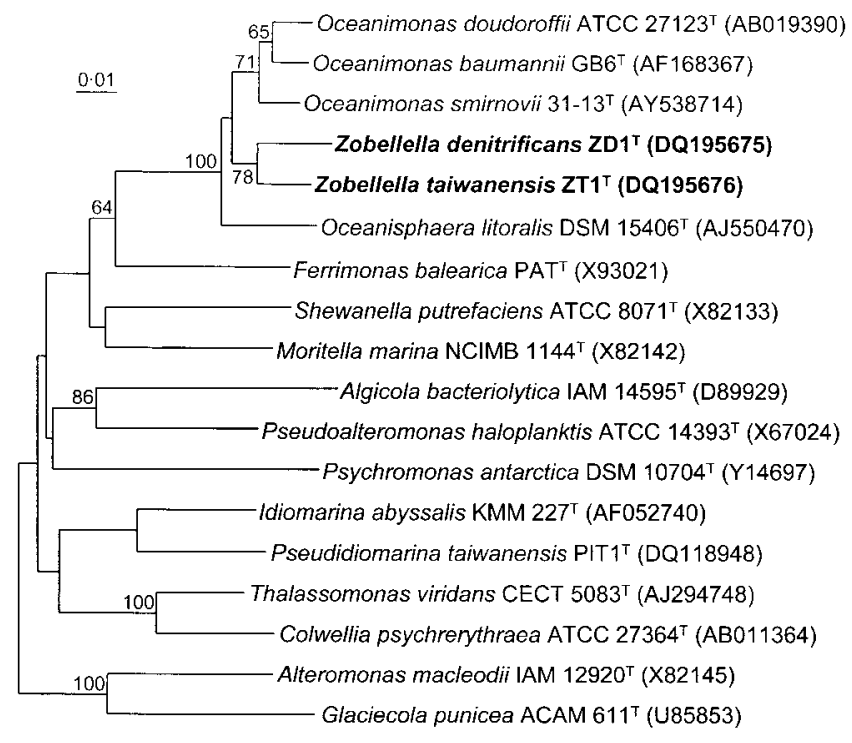

Fig. 2. Unrooted phylogenetic tree derived from neighbourjoining analysis of the 16S rRNA gene sequences of strains $\mathrm{ZD}^{\top}{ }^{\top}$ and $\mathrm{ZT}^{\top}{ }^{\top}$ and related genera of the Alteromonas-like Gammaproteobacteria. GenBank accession numbers are given in parentheses. Numbers above nodes represent bootstrap confidence values obtained with 100 resamplings; values below 60 are not shown. Bar, $1 \%$ estimated sequence divergence.
Table 1. Cellular fatty acid contents (\%) of strains $Z \mathrm{DD} 1^{\top}$ and $\mathrm{ZT} 1^{\top}$ and species of Oceanimonas and Oceanisphaera

Strains: $1, \mathrm{ZD1}^{\mathrm{T}}$ (data from this study); $2, \mathrm{ZT}^{\mathrm{T}}$ (this study); 3, Oceanimonas doudoroffii ATCC $27123^{\mathrm{T}}$ (Brown et al., 2001);

4, Oceanimonas baumannii ATCC $700832^{\mathrm{T}}$ (Brown et al., 2001);

5, Oceanimonas smirnovii $31-13^{\mathrm{T}}$ (Ivanova et al., 2005);

6, Oceanisphaera litoralis KMM $3654^{\mathrm{T}}$ (Romanenko et al., 2003). - , Not detected.

\begin{tabular}{|lcccccc|}
\hline Fatty acid & $\mathbf{1}$ & $\mathbf{2}$ & $\mathbf{3}$ & $\mathbf{4}$ & $\mathbf{5}$ & $\mathbf{6}$ \\
\hline $\mathrm{C}_{12: 0}$ & $5 \cdot 3$ & $4 \cdot 8$ & $7 \cdot 0$ & $3 \cdot 0$ & $1 \cdot 5$ & - \\
$\mathrm{C}_{12: 0} 3-\mathrm{OH}$ & $0 \cdot 2$ & - & - & - & - & - \\
$\mathrm{C}_{14: 0}$ & $0 \cdot 6$ & $0 \cdot 9$ & - & - & $0 \cdot 6$ & - \\
$\mathrm{C}_{14: 0} 3-\mathrm{OH}$ & $6 \cdot 6$ & $6 \cdot 4$ & - & - & - & - \\
$\mathrm{C}_{15: 0}$ anteiso & - & - & - & - & $0 \cdot 5$ & - \\
$\mathrm{C}_{15: 0}$ & - & - & - & - & $0 \cdot 6$ & $1 \cdot 8$ \\
$\mathrm{C}_{16: 1} \omega 7 c$ & $27 \cdot 5$ & $29 \cdot 4$ & $42 \cdot 0$ & $45 \cdot 0$ & $40 \cdot 1$ & $41 \cdot 0$ \\
$\mathrm{C}_{16: 0}$ & $20 \cdot 1$ & $22 \cdot 0$ & $21 \cdot 2$ & $20 \cdot 0$ & $24 \cdot 1$ & $21 \cdot 6$ \\
$\mathrm{C}_{16: 0}$ iso & - & - & - & - & - & $1 \cdot 6$ \\
$\mathrm{C}_{17: 0}$ & - & - & - & - & $0 \cdot 7$ & $1 \cdot 9$ \\
$\mathrm{C}_{17: 0}$ anteiso & - & - & - & - & $0 \cdot 9$ & - \\
$\mathrm{C}_{17: 1} \omega 8 c$ & - & - & - & - & - & $1 \cdot 9$ \\
$\mathrm{C}_{18: 0}$ & $1 \cdot 1$ & $2 \cdot 0$ & - & - & $0 \cdot 9$ & - \\
$\mathrm{C}_{18: 1} \omega 7 c$ & $35 \cdot 7$ & $32 \cdot 6$ & $29 \cdot 9$ & $32 \cdot 0$ & $29 \cdot 2$ & $27 \cdot 5$ \\
$\mathrm{C}_{20: 1} \omega 7 c$ & $0 \cdot 2$ & $0 \cdot 2$ & - & - & - & - \\
\hline
\end{tabular}

Oceanisphaera. Moreover, only the novel isolates contained $\mathrm{C}_{14: 0} 3-\mathrm{OH}(6 \cdot 4-6 \cdot 6 \%)$. Both isolates contained phosphatidylethanolamine $(47 \cdot 2-51 \cdot 0 \%)$, phosphatidylglycerol $(40 \cdot 8-41 \cdot 7 \%)$ and diphosphatidylglycerol $(8 \cdot 2-11 \cdot 1 \%)$ as the major polar lipids. These polar lipids also accounted for the total phospholipids in Oceanimonas (Brown et al., 2001; Ivanova et al., 2005) and Oceanisphaera (Romanenko et al., 2003). However, relatively low levels of diphosphatidylglycerol (trace to $3 \cdot 1 \%$ ) were detected in Oceanimonas doudoroffii and Oceanimonas baumannii (Brown et al., 2001).

Based on $\mathrm{G}+\mathrm{C}$ contents, profiles of fatty acids and polar lipids and $16 \mathrm{~S}$ rRNA gene-based phylogeny, it is proposed that strains $\mathrm{ZD} 1^{\mathrm{T}}$ and $\mathrm{ZT} 1^{\mathrm{T}}$ represent two novel species in a new genus rather than novel species of Oceanimonas or Oceanisphaera. The DNA relatedness value between strains $\mathrm{ZD1}^{\mathrm{T}}$ and $\mathrm{ZT}^{\mathrm{T}}$ was $58.5 \%$ when genomic DNA of the former strain was used as a probe. The strains could be classified as two different genomic species according to this data.

Strains $\mathrm{ZD1} 1^{\mathrm{T}}$ and $\mathrm{ZT1} 1^{\mathrm{T}}$ were Gram-negative and oxidaseand catalase-positive. Colonies produced on PY plate medium were circular, off-white and non-luminescent. Cells grown in PY broth, which appeared to be straight, motile rods, normally possessed a single polar flagellum, as revealed by TEM (see electron micrographs available as Supplementary Fig. S1 in IJSEM Online). Both strains were facultative anaerobes capable of fermenting glucose, sucrose, ribose, maltose, melezitose, starch, mannitol and 
myo-inositol. Their activity to reduce $\mathrm{NO}_{3}^{-}$to $\mathrm{N}_{2} \mathrm{O}$ and further to $\mathrm{N}_{2}$ was detected by the $\mathrm{C}_{2} \mathrm{H}_{2}$ blockage and $\mathrm{N}_{2} \mathrm{O}$ reduction procedures. Additional phenotypic characterization data are given below in the species descriptions.

Phenotypically, strains $\mathrm{ZD1}^{\mathrm{T}}$ and $\mathrm{ZT1}^{\mathrm{T}}$ could be differentiated from each other by different reactions in several phenotypic tests, including growth in $14 \% \mathrm{NaCl}$, fermentation of galactose, melibiose and trehalose and utilization of galactose, melibiose, trehalose and adonitol as sole carbon and energy sources. Both strains could be distinguished from species of Oceanimonas and Oceanisphaera in that they were capable of fermentative metabolism. The ability to grow in the absence of $\mathrm{NaCl}$ also distinguished the strains from these species, with the exception of Oceanimonas smirnovii. Other phenotypic characteristics useful for differentiating strains $\mathrm{ZD}^{\mathrm{T}}$ and $\mathrm{ZT} 1^{\mathrm{T}}$ from species of Oceanimonas and Oceanisphaera are listed in Table 2.

Phylogenetic, chemotaxonomic and phenotypic data accumulated in this study strongly support the establishment of two different species in a novel genus. It is, therefore, proposed that strains $\mathrm{ZD}^{\mathrm{T}}$ and $\mathrm{ZT} 1^{\mathrm{T}}$ should be classified in the genus Zobellella gen. nov., as the type strains of Zobellella denitrificans sp. nov. and Zobellella taiwanensis sp. nov., respectively, with Zobellella denitrificans as the type species.

Table 2. Characteristics useful for differentiating strains $\mathrm{ZD} 1^{\top}$ and $\mathrm{ZT} 1^{\top}$ from species of Oceanimonas and Oceanisphaera

Strains: $1, \mathrm{ZD}^{\mathrm{T}}$ (data from this study); $2, \mathrm{ZT}^{\mathrm{T}}$ (this study); 3, Oceanimonas doudoroffii ATCC 27123 ${ }^{\mathrm{T}}$ (Brown et al., 2001); 4, Oceanimonas baumannii ATCC $700832^{\mathrm{T}}$ (Brown et al., 2001); 5, Oceanimonas smirnovii 31-13 ${ }^{\mathrm{T}}$ (Ivanova et al., 2005); 6, Oceanisphaera litoralis KMM $3654^{\mathrm{T}}$ (Romanenko et al., 2003). +, Positive; -, negative; $\mathrm{W}$, weakly positive; ND, no data available. All species grow at $10-40{ }^{\circ} \mathrm{C}$ and in $3 \% \mathrm{NaCl}$.

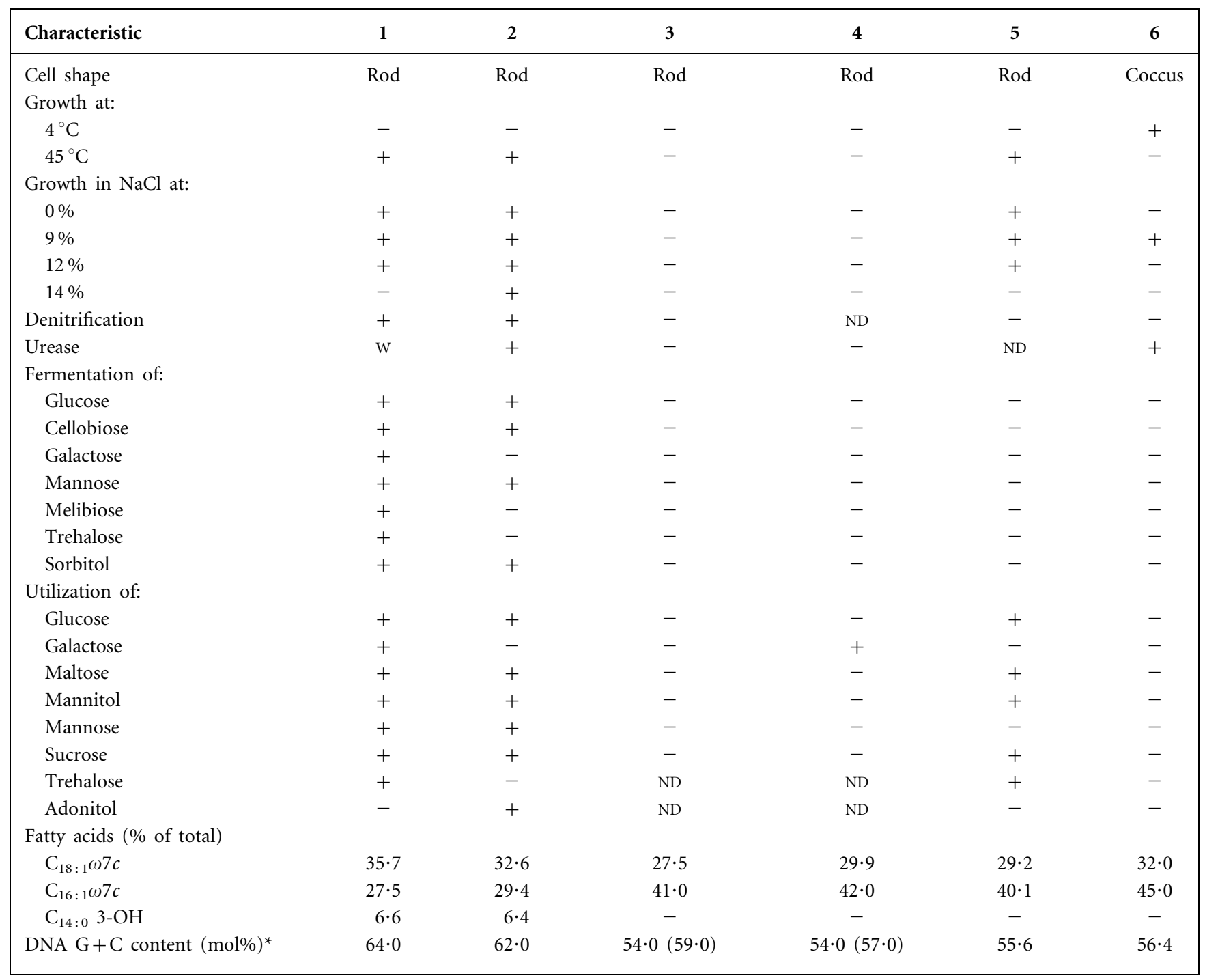

${ }^{\star}$ Data in parentheses are from Ivanova et al. (2005). 
Zobellella denitrificans and Zobellella taiwanensis are the only species in the Alteromonas-like Gammaproteobacteria that possess DNA $\mathrm{G}+\mathrm{C}$ contents greater than $60 \mathrm{~mol} \%$. They have so far been found only in the sediment of estuarine mangrove forests. However, their tolerance of rather wide ranges of temperatures and salinities and ability to grow in the absence of oxygen and organic growth factors suggest that these bacteria may also occur in other habitats, including saline and non-saline environments.

\section{Description of Zobellella gen. nov.}

Zobellella (Zo.bell.el'la. N.L. dim. ending -ella; N.L. fem. n. Zobellella named after C. E. ZoBell, a pioneer marine microbiologist).

Members are heterotrophic, Gram-negative rods belonging to the Gammaproteobacteria. Cells grown in broth cultures are motile by means of a single, polar flagellum. $\mathrm{NaCl}$ stimulates growth, but is not an absolute requirement. Facultative anaerobes capable of both respiratory and fermentative metabolism. Mesophilic; grow optimally at $30-35^{\circ} \mathrm{C}$, but do not grow at 4 or $50^{\circ} \mathrm{C}$. Oxidase- and catalase-positive. $\mathrm{C}_{18: 1} \omega 7 \mathrm{c}$ is the most abundant fatty acid; $\mathrm{C}_{16: 1} \omega 7 c$ and $\mathrm{C}_{16: 0}$ are the next most abundant fatty acids. Major constituents of polar lipids are the phospholipids phosphatidylglycerol, phosphatidylethanolamine and diphosphatidylglycerol. The DNA G+C contents of the strains so far examined are $62 \cdot 0-64 \cdot 0 \mathrm{~mol} \%$. The type species is Zobellella denitrificans.

\section{Description of Zobellella denitrificans sp. nov.}

Zobellella denitrificans (de.ni.tri' fi.cans. N.L. v. denitrifico to denitrify; N.L. part. adj. denitrificans denitrifying).

Description is as for the genus with the following additional characteristics. Cells during late exponential to early stationary phase of growth in broth cultures are straight rods, approximately $1.6-2.6 \mu \mathrm{m}$ long by $0.6-0.8 \mu \mathrm{m}$ wide. Colonies produced on PY agar plates at $30^{\circ} \mathrm{C}$ for $48-60 \mathrm{~h}$ are approximately $1 \cdot 5-4.0 \mathrm{~mm}$ in diameter, circular, offwhite and non-luminescent, with an entire edge. Swarming does not occur. Capable of complete denitrification, i.e. capable of reducing $\mathrm{NO}_{3}^{-}$to $\mathrm{N}_{2}$ via $\mathrm{NO}_{2}^{-}$and $\mathrm{N}_{2} \mathrm{O}$. Able to ferment glucose, cellobiose, galactose, maltose, mannose, melezitose, melibiose, ribose, sucrose, trehalose, starch, mannitol, myo-inositol and sorbitol with production of acid, but no gas. Unable to ferment $\mathrm{D}$-arabinose, L-arabinose, lactose, xylose or dulcitol. Growth occurs at $10-45^{\circ} \mathrm{C}$, with optimum growth at $30-35^{\circ} \mathrm{C}$. Growth occurs at $\mathrm{pH}$ 6-10, with optimum growth at $\mathrm{pH} 7-8$. Growth occurs in $0-12 \% \mathrm{NaCl}$, with optimum growth in $1-3 \%$; no growth is observed in 13-14\% NaCl. Weakly positive for urease. Negative for arginine dihydrolase, lysine decarboxylase, ornithine decarboxylase, agarase, amylase, DNase, gelatinase and lipase. $\mathrm{H}_{2} \mathrm{~S}$ is not produced from thiosulfate. Indole is not produced from tryptophan. Cellobiose, glucose, galactose, maltose, mannose, mannitol, melezitose, melibiose, myo-inositol, ribose, sorbitol, starch, sucrose and trehalose can be utilized as sole carbon and energy sources, but D-arabinose, L-arabinose, lactose, xylose, adonitol and dulcitol cannot. The following constitutive enzyme activities are detected in API ZYM tests: acid phosphatase, alkaline phosphatase, esterase (C4), esterase lipase (C8), $\alpha$-galactosidase, $\alpha$-glucosidase, leucine arylamidase, naphthol-AS-BI-phosphohydrolase, trypsin and valine arylamidase. Susceptible to ampicillin $(10 \mu \mathrm{g})$, carbenicillin $(100 \mu \mathrm{g})$, cephalothin $(30 \mu \mathrm{g})$, chloramphenicol $(30 \mu \mathrm{g})$, colistin $(10 \mu \mathrm{g})$, gentamicin $(10 \mu \mathrm{g})$, nalidixic acid $(30 \mu \mathrm{g})$, neomycin $(30 \mu \mathrm{g})$, penicillin $\mathrm{G}(10 \mathrm{U})$, polymyxin $\mathrm{B}(300 \mathrm{U})$ and tetracycline $(30 \mu \mathrm{g})$; intermediate susceptibility to kanamycin $(30 \mu \mathrm{g})$; resistant to clindamycin $(2 \mu \mathrm{g})$, erythromycin $(15 \mu \mathrm{g})$, lincomycin $(2 \mu \mathrm{g})$, novobiocin $(30 \mu \mathrm{g})$, oxacillin $(1 \mu \mathrm{g})$, streptomycin $(10 \mu \mathrm{g})$ and vancomycin $(30 \mu \mathrm{g})$.

The type strain is $\mathrm{ZD1}^{\mathrm{T}}\left(=\mathrm{BCRC} 17493^{\mathrm{T}}=\mathrm{JCM} 13380^{\mathrm{T}}\right)$, isolated from a sediment sample collected from the estuarine mangrove ecosystem of Chungkang, Miaoli County, Taiwan. It has a DNA G $+\mathrm{C}$ content of $64 \cdot 0 \mathrm{~mol} \%$.

\section{Description of Zobellella taiwanensis sp. nov.}

Zobellella taiwanensis (tai.wan.en'sis. N.L. fem. adj. taiwanensis pertaining to Taiwan, where the type strain was isolated).

Description is as for the genus and the species description of Zobellella denitrificans with the following modifications. Growth occurs in $0-14 \% \mathrm{NaCl}$, with optimum growth at $1-3 \%$. Cells are $1 \cdot 0-1 \cdot 9 \mu \mathrm{m}$ long by $0 \cdot 6-0 \cdot 7 \mu \mathrm{m}$ wide. Positive for urease test. Unable to ferment galactose, melibiose or trehalose. Adonitol can be utilized as a sole carbon and energy source, but not galactose, melibiose or trehalose. In API ZYM tests, $\alpha$-galactosidase, esterase lipase (C8), naphthol-AS-BI-phosphohydrolase and trypsin activities are not detected. Resistant to ampicillin $(10 \mu \mathrm{g})$, carbenicillin $(100 \mu \mathrm{g})$ and penicillin $\mathrm{G}(10 \mathrm{U})$.

The type strain is $\mathrm{ZT}^{\mathrm{T}}\left(=\mathrm{BCRC} 17494^{\mathrm{T}}=\mathrm{JCM} 13381^{\mathrm{T}}\right)$, isolated from a sediment sample collected from the estuarine mangrove ecosystem of Kuantu, Taipei, Taiwan. It has a DNA G + C content of $62 \cdot 0 \mathrm{~mol} \%$.

\section{Acknowledgements}

We are very grateful to Dr J.-S. Chen, School of Medicine, China Medical University, Taiwan, for advice and critical reading of the manuscript. This study was supported by grants NSC91-2313-B-002327, NSC92-3114-B-002-014 and NSC92-2313-B-002-084 from the National Science Council.

\section{References}

Bligh, E. G. \& Dyer, W. J. (1959). A rapid method of total lipid extraction and purification. Can J Med Sci 37, 911-917.

Brettar, I., Christen, R. \& Höfle, M. G. (2002). Shewanella denitrificans sp. nov., a vigorously denitrifying bacterium isolated from the 
oxic-anoxic interface of the Gotland Deep in the central Baltic Sea. Int J Syst Evol Microbiol 52, 2211-2217.

Brown, G. R., Sutcliffe, I. C. \& Cummings, S. P. (2001). Reclassification of [Pseudomonas] doudoroffii (Baumann et al. 1983) into the genus Oceanomonas gen. nov. as Oceanomonas doudoroffii comb. nov., and description of a phenol-degrading bacterium from estuarine water as Oceanomonas baumannii sp. nov. Int J Syst Evol Microbiol 51, 67-72.

Felsenstein, J. (1981). Evolutionary trees from DNA sequences: a maximum likelihood approach. J Mol Evol 17, 368-376.

Felsenstein, J. (1985). Confidence limits on phylogenies: an approach using the bootstrap. Evolution 39, 783-791.

Fitch, W. M. (1971). Toward defining the course of evolution: minimum change for a specific tree topology. Syst Zool 20, 406-416.

Ivanova, E. P., Flavier, S. \& Christen, R. (2004). Phylogenetic relationships among marine Alteromonas-like proteobacteria: emended description of the family Alteromonadaceae and proposal of Pseudoalteromonadaceae fam. nov., Colwelliaceae fam. nov., Shewanellaceae fam. nov., Moritellaceae fam. nov., Ferrimonadaceae fam. nov., Idiomarinaceae fam. nov. and Psychromonadaceae fam. nov. Int J Syst Evol Microbiol 54, 1773-1788.

Ivanova, E. P., Onyshchenko, O. M., Christen, R., Zhukova, N. V., Lysenko, A. M., Shevchenko, L. S., Buljan, V., Hambly, B. \& Kiprianova, E. A. (2005). Oceanimonas smirnovii sp. nov., a novel organism isolated from the Black Sea. Syst Appl Microbiol 28, 131-136.

Lane, D. J. (1991). 16S/23S rRNA sequencing. In Nucleic Acid Techniques in Bacterial Systematics, pp. 115-175. Edited by E. Stackebrandt \& M. Goodfellow. Chichester: Wiley.

Romanenko, L. A., Schumann, P., Zhukova, N. V., Rohde, M., Mikhailov, V. V. \& Stackebrandt, E. (2003). Oceanisphaera litoralis gen. nov., sp. nov., a novel halophilic bacterium from marine bottom sediments. Int J Syst Evol Microbiol 53, 1885-1888.

Sasser, M. (1990). Identification of bacteria by gas chromatography of cellular fatty acids. Technical Note 101. Newark, DE: MIDI.
Shieh, W. Y. \& Liu, C. M. (1996). Denitrification by a novel halophilic fermentative bacterium. Can J Microbiol 42, 507-514.

Shieh, W. Y., Chen, A.-L. \& Chiu, H.-H. (2000). Vibrio aerogenes sp. nov., a facultatively anaerobic marine bacterium that ferments glucose with gas production. Int J Syst Evol Microbiol 50, 321-329.

Shieh, W. Y., Chen, Y.-W., Chaw, S.-M. \& Chiu, H.-H. (2003a). Vibrio ruber sp. nov., a red, facultatively anaerobic, marine bacterium isolated from sea water. Int J Syst Evol Microbiol 53, 479-484.

Shieh, W. Y., Jean, W. D., Lin, Y.-T. \& Tseng, M. (2003b). Marinobacter lutaoensis sp. nov., a thermotolerant marine bacterium isolated from a coastal hot spring in Lutao, Taiwan. Can J Microbiol 49, 244-252.

Shieh, W. Y., Lin, Y.-T. \& Jean, W. D. (2004). Pseudovibrio denitrificans gen. nov., sp. nov., a marine, facultatively anaerobic, fermentative bacterium capable of denitrification. Int J Syst Evol Microbiol 54, 2307-2312.

Smibert, R. M. \& Krieg, N. R. (1994). Phenotypic characterization. In Methods for General and Molecular Bacteriology, pp. 607-654. Edited by P. Gerhardt, R. G. E. Murray, W. A. Wood \& N. R. Krieg. Washington, DC: American Society for Microbiology.

Vaskovsky, V. E. \& Terekhova, T. A. (1979). HPTLC of phospholipid mixtures containing phosphatidylglycerol. J High Resolut Chromatogr Chromatogr Commun 2, 671-672.

Vaskovsky, V. E., Kostetsky, E. Y. \& Vasendin, I. M. (1975). A universal reagent for phospholipid analysis. J Chromatogr 114, 129-141.

Xu, M., Guo, J., Cen, Y., Zhong, X., Cao, W. \& Sun, G. (2005). Shewanella decolorationis sp. nov., a dye-decolorizing bacterium isolated from activated sludge of a waste-water treatment plant. Int J Syst Evol Microbiol 55, 363-368.

Zhao, J.-S., Manno, D., Beaulieu, C., Paquet, L. \& Hawari, J. (2005). Shewanella sediminis sp. nov., a novel $\mathrm{Na}^{+}$-requiring and hexahydro-1,3,5-trinitro-1,3,5-triazine-degrading bacterium from marine sediment. Int J Syst Evol Microbiol 55, 1511-1520. 